\title{
Microbial Fuel Cells: A Source of Bioenergy
}

\section{Anand Parkash*}

Department of Chemical Engineering, Mehran University of Engineering and Technology, Jamshoro, Pakistan

\begin{abstract}
The demands of energy in the world continue to accelerate and this triggers the global energy crisis and environmental Pollution. The reliance on fossil fuels (oil and gas) is unsustainable because of its finite, depleting supplies and impact on environment. As a result researchers are focusing on alternative, renewable and carbon neutral energy sources which are necessary for environmental and economic sustainability. MFC is a bioreactor that converts chemical energy present in the organic or inorganic compound substrates to electrical energy through catalytic reactions of microorganisms. Many substrates involve in generating electricity including carbohydrates, proteins, volatile acids, cellulose and wastewaters used as feed in MFC studies. MFC has a wide range of applications, including serving as household electrical generators and powering items such as small portable electronic devices boats, automobiles, electronics in space and self-feeding robots. The construction and analysis of MFCs requires knowledge at both scientific and engineering fields, ranging from microbiology and electrochemistry to materials and environmental engineering. We conclude that for further development of MFC technology a greater focus on the understanding of its components, microbial processes, factors of limitations and designs of the construction the in MFC systems is mandatory, in order to be simplified and large scale system developed; so that it will be cost-effective and to increase electricity production. This paper aimed to review on the current microbiology knowledge in electricity production, the materials and methods used to build the technology and the applications to MFC technology also highlighted.
\end{abstract}

Keywords: Microbial fuel cell; Microorganisms; Electricity; Substrate; Organic matter

\section{Introduction}

The microbial fuel cell (MFC) has gained much attention because of its ability to generate power from organic or inorganic compounds via microorganisms. Around one hundred years ago, the technology of generating electricity through bacteria was found [1-3], but it did not gain much attention. Due to the ability to convert chemical energy to electrical energy, MFCs have many potential applications, such as electricity generation, bio-hydrogen production, wastewater treatment and biosensor [3-5]. Therefore, the number of studies focused on MFCs increased greatly since early 1990s. Many previous studies concentrated on mediator-MFCs as the power generation could be enhanced. The mediators facilitate the electron shuttling so that the power output can be increased significantly, but the mediators, such as potassium ferricyanide, limit the development of MFCs because of their toxicity to microorganisms and cost [6-8]. Since most of the mediators are expensive and toxic, a microbial fuel cell employing mediator has not been commercialized. In 1999, it was found that mediators did not have to be added to MFCs, which was a significant development in MFCs [911]. This type of MFCs was a new generation at that time and classified as mediator-less MFC. Many studies on mediator-less MFC focused on discovering the mechanisms of how bacteria transfer electrons. Electron transfer mechanisms will be discussed in the following section of this review. By reducing the expense by eliminating the mediators, MFCs became more attractive in real application, for instance, wastewater treatment and power generation [12]. Microorganisms oxidize substrates in the anodic chamber to produce electrons and protons, while producing carbon dioxide as an oxidation product. Electrons attached on anode (negative terminal) flow to the cathode (positive terminal) through an external circuit. Protons migrate across the proton/cation exchange membrane to combine with electrons to form water if oxygen is provided $[13,14]$ or to form ferrocyanide if ferricyanide is provided. Therefore, a positive current flow from the positive terminal to the negative terminal and this direction is opposite to electron flow. This is how MFCs generate electricity through microorganisms (Figure 1). In MFCs, oxidation of organic carbon sources does not contribute net carbon dioxide to the atmosphere, and there is no need for extensive pre-processing of the fuel or expensive catalysts [15]. These are the major advantages of MFCs over hydrogen fuel cells, however, the power production by MFCs is currently limited mainly due to either high internal resistance or efficiency of the cathodic reaction, and feasibility of scale-up of MFCs is restricted

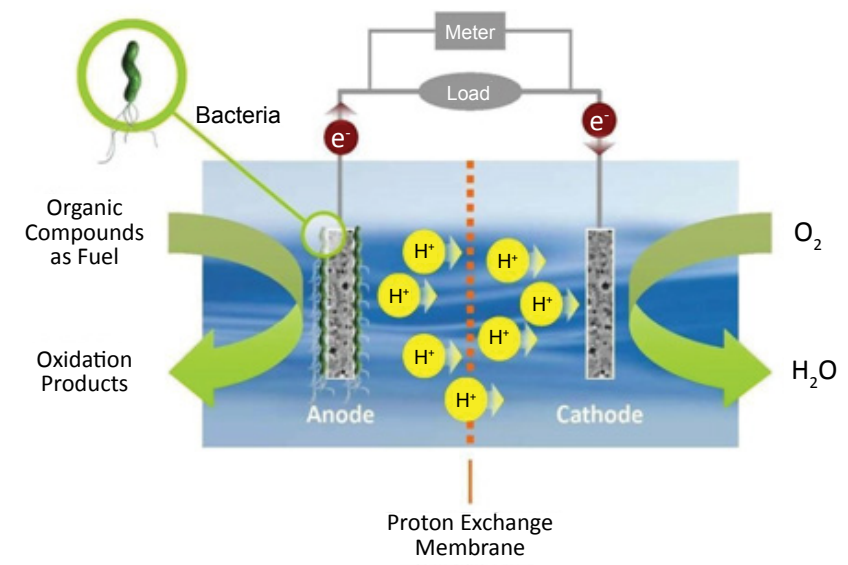

Figure 1: Schematic diagram of two-chamber microbial fuel cells (Du et al. [16]).

*Corresponding author: Anand Parkash, Department of Chemical Engineering Mehran University of Engineering and Technology, Jamshoro, Pakistan, Tel: +92 22 2772250; E-mail: parwani_anand@yahoo.com

Received May 14, 2016; Accepted May 25, 2016; Published June 04, 2016

Citation: Parkash A (2016) Microbial Fuel Cells: A Source of Bioenergy. J Microb Biochem Technol 8: 247-255. doi: 10.4172/1948-5948.1000293

Copyright: ( $) 2016$ Parkash A. This is an open-access article distributed under the terms of the Creative Commons Attribution License, which permits unrestricted use, distribution, and reproduction in any medium, provided the original author and source are credited. 
by the high cost of membranes. With the appropriate optimization of architecture or suitable storage of produced energy, microbial fuel cells are able to power a wide range of widely used devices: for example, store the energy in an external storage device (e.g. capacitor) and dispense that energy intermittently in bursts of high-power when needed [16-18], power sensors for environmental parameters monitoring at various time intervals rather than continuously [19], provide power for implantable medical devices placed in human large intestine by utilizing intestinal contents [20], power devices placed on the seafloor or under water environment [21].

The performance of MFCs can be influenced by several factors. Gil et al. [19] reported that the factors include the rates of substrate oxidation, electron transfer to the electrode by the microbes, the resistance of the circuit, proton transport to the cathode through the membrane, oxygen supply and reduction in the cathode. In recent years, publications related to microbial fuel cell research have increased rapidly with different favors. Several excellent reviews have come out with different emphasis, such as MFC designs and materials [2224], discoveries of the capabilities of the microorganisms [25-27], performance of different substrates for power generation [26]. The factors of architecture, electron transfer mechanisms and substrates will be mainly reviewed in this work here. Furthermore, a few promising applications of MFCs will be discussed.

\section{Architecture of Microbial Fuel Cells}

MFCs are being constructed in a diversity of architectures, and different types of MFCs are usually evaluated by power output, Coulombic efficiency, stability, and longevity. Moreover, in the real application, cost of the materials and feasibility scaling up the architectures also need to be taken into consideration.

\section{Two-Chamber MFCs}

The conventional design of microbial fuel cells consists of one anode chamber and one cathode chamber, which are connected by a bridge and separated by a proton/cation exchange membrane. This typical two-chamber design of MFCs is frequently operated in batch mode and fed-batch mode. The purposes of proton exchange membrane (PEM), such as Nafion 117, are to separate the liquids in each chamber and allow protons to flow from anode to cathode [27]. Sometimes, PEM can be replaced by cation exchange membrane (CEM), as it is less expensive and stronger [28]. Furthermore, the CEM in two-chamber MFCs could be replaced by a salt bridge, which consisted of a tube filled with agar and salt and then capped with porous caps [29], but the power output was as low as $2.2 \mathrm{~mW} / \mathrm{m}^{2}$, which was due to the very high internal resistance. Both PEM and CEM help to reduce oxygen diffusion into anodic chamber. Liu and Logan demonstrated that if PEM was removed in a single-chamber MFC, the oxygen diffusion increased, although the internal resistance was reduced. Cathodes used for MFCs are often either catalyst coated carbon electrodes immersed in water, or they are plain carbon electrodes in a ferricyanide solution. If a catalyst coated carbon electrode is used, the dissolved oxygen is the electron acceptor, and the cathodic reaction is $\mathrm{O}_{2}+4 \mathrm{H}^{+}+4 \mathrm{e}^{-}=2 \mathrm{H}_{2} \mathrm{O}$. Platinum is a well-known oxygen reduction catalyst. But platinum is expensive so it needs to be either substituted by cheaper, non-noble metal catalysts (e.g. cobalt) or to be reduced in amount on the electrode [30-32]. The cathodic reaction was related to the Pt loading on the electrode and power/current density was directly proportional to catalyst loading on the cathodic electrode. For example, the maximum power density was increased over twice as the Pt loading was increased from 0.5 to 3.0 $\mathrm{mg} \mathrm{Pt} / \mathrm{cm}^{2}$ [32-34]. In a ferricyanide solution, plain carbon electrode uses ferricyanide as the electron acceptor and the cathodic reaction is $\mathrm{Fe}(\mathrm{CN})_{6}^{3-}+\mathrm{e}^{-}=\mathrm{Fe}(\mathrm{CN})_{6}^{4-}$. Because ferricyanide in the cathode chamber is reduced to ferrocyanide, the chemical must be replaced after it is depleted. Thus, cathodes with ferricyanide are not economic and environmental friendly although the maximum power could increase by $50-80 \%$ if ferricyanide is used instead of dissolved oxygen $[35,36]$. High power densities involved ferricyanide was obtained by Rabaey et al. as well [1]. In Rabaey et al.s studies, power densities were as high as $3.6 \mathrm{~W} / \mathrm{m}^{2}$ and $4.31 \mathrm{~W} / \mathrm{m}^{2}$ with plain graphite electrodes in twochamber systems, which used $\mathrm{K}_{3} \mathrm{Fe}(\mathrm{CN})_{6}$ as electron acceptors. Instead of ferricyanide, oxygen can be constantly replenished by bubbling the water with air, which makes MFC systems more sustainable [1]. That is the reason that many studies suspend cathodes in liquid with sparged air of the two-chamber MFCs obtained power generation of $43 \mathrm{~mW} / \mathrm{m}^{2}$ with dissolved oxygen into Pt-carbon cathode chamber and stated that power densities in two-chamber MFCs are possible to be increased by improvements of cathode, such as increase concentration of dissolved oxygen. However, aerating air into cathodic chamber causes another disadvantage of a two-chamber MFC besides high internal resistance, because aeration consumes more energy. Unlike aqueous-cathode MFCs, air-cathode MFCs does not require the cathode to be placed in water.

\section{Air-Chamber MFCs}

As mentioned above, power output of two-chamber MFCs can be improved by increasing the efficiency of the cathode, such as using ferricyanide. But two-chamber MFCs are primarily used in laboratory scale and cannot be adapted for continuous treatment of organic matter due to the demand of oxygenated water. In an alternative architecture without aqueous cathode, cathodic electrode is bonded directly to proton exchange membrane so that air can be directly reduced [37-41]. This is the air-cathode MFC [42] (Figure 2). The earliest air-cathode MFC architecture was designed and reported that an oxygen gas diffusion electrode could be used as a cathode in bioelectro-chemical fuel cell [43]. But this air-cathode design has not drawn much attention in MFC research until Liu reported the air-cathode MFC could produce much greater power than typical aqueous-cathode ones. In this study, they developed the air-cathode configuration with presence and absence of PEM, and maximum power output was $262 \mathrm{~mW} / \mathrm{m}^{2}$ using glucose with PEM and $494 \mathrm{~mW} / \mathrm{m}^{2}$ without PEM. However,

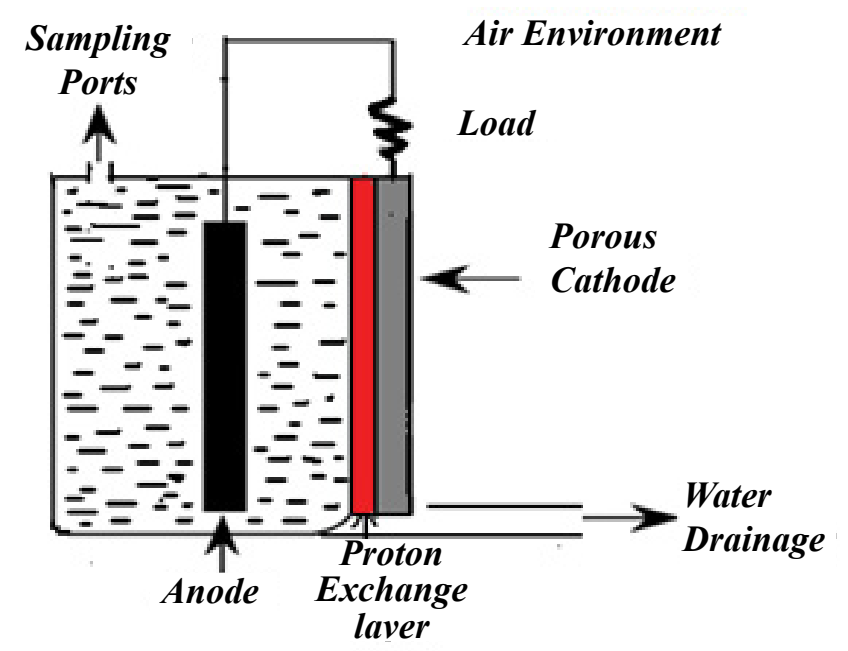

Figure 2: Schematic diagram of single-chamber microbial fuel cells (Pant et al. $[62,63])$. 
the Coulombic efficiency was much lower with absence of PEM due to oxygen diffusion into the anode. Further tests in Liu et al's study were conducted with acetate and butyrate in the same reactor in the absence of the CEM. Other studies have been conducted to examine power outputs in air-cathode MFCs, and the results were $506 \mathrm{~mW} / \mathrm{m}^{2}$ with acetate and $305 \mathrm{~mW} / \mathrm{m}^{2}$ butyrate in the same air-cathode design without any membrane [43].

The architecture of air-cathode MFCs is aimed to optimize some characteristics of two-chamber MFCs, such as low relative power output, high cost of cathode catalysts and membranes, energy requirement for intensive air/oxygen sparging. Another advantage of the air-cathode over the two-chamber is the reduction of the high internal resistance of MFCs, which is a key factor to enhance electricity production. For example, internal resistance ranged from $1239 \Omega$ to $\Omega$ among 1344 different membranes in aqueous-cathode MFCs and 84 $\Omega-98 \Omega$ in air-cathode MFCs. However, oxygen diffusion to anaerobic anode chamber increases due to cathode exposure to air and removal of proton/anion exchange membrane, which could cause low electron and energy recoveries [44-47].

\section{Other Designs of MFCs}

Voltage generated by MFCs remains limited and cannot exceed a theoretical open circuit voltage of $1.14 \mathrm{~V}$ as determined by the NADH $(-0.32 \mathrm{~V})$ and pure oxygen $(+0.82 \mathrm{~V})$ redox potentials, even neglecting the internal losses [48]. Other optimized architectures of MFCs were constructed. For example, tubular/up flow architecture [49] and stacked microbial fuel cells [50]. Jang et al. [10] designed a tubular reactor architecture working in continuous flow mode, the flow moving through an anode chamber and then directly up into the cathode chamber in the same column. They claimed the up-flow reactor had several advantages over conventional designs, such as a higher affinity for oxygen with cathode [51], combining the benefits of the upflow anaerobic sludge blanket system with two-chamber MFC [52]. These advantages result in improving both electricity generation and wastewater treatment. Referring to the idea of connecting several fuel cells in series to add the voltages, connecting several MFCs in series or parallel can enhance voltage or current output [53]. Aelterman designed a stacked system of MFCs, which was used to examine the performance of MFCs connected in series or parallel. In this system, the separated MFCs were electrically connected in series, or parallel using copper wires connected to the electrodes and held together by screw bolts. The result obtained by Aelterman demonstrated that the parallel-connected system could exhibit higher maximum bioeletrochemical reaction rate. Applying stacked MFCs to wastewater treatment application can enhance the chemical oxygen demand removal compared to a single cell. All of the optimizations of MFCs' configuration or architecture aim to reduce the internal resistance and increase the cell power output. Chae et al. [9] claimed better understanding of the bacterial community or dominant species, which contributed to the exoelectron transfers, could help to achieve better performance of MFCs.

\section{Microorganisms Inoculated in Microbial Fuel Cells}

Fuel cells are able to generate electricity from many different chemicals by oxidation of the chemicals at the anode and reduction at the cathode. MFCs do not need to use metal catalysts at the anode; instead, they use microorganisms that biologically oxidize organic matter and transfer electrons to the electrode. Logan defined the microorganisms as exoelectrogens due to their capability of exocellular electron transfer. Other researchers described the microorganisms as electrochemically active bacteria [54-56], anode respiring bacteria [57] and electricigens [45]. The microorganisms, which can be inoculated in MFCs for electricity generation, are found in marine sediment, soil, wastewater, and fresh water sediment or activated sludge [58]. A number of species, such as Geobacter, Shewanella, Pseudomonas, Clostridium and Desulfuromonas, are often inoculated into MFCs or MECs for electricity and hydrogen productions, and they are able to oxidize acetate, ethanol, lactate, butyrate, or propionate as substrate [59]. Therefore, the electron transfer mechanisms in anode chamber of MFCs are a crucial issue of studying MFCs' working principles. So far, there are several known mechanisms of how bacteria transfer electrons to electrode surfaces. In MFC, the anodic electrode potential is developed when electrons are available to the electrode. But some bacterial species cannot transfer or release electrons to electrode through their electron transport systems because of the non-conductive nature of the cell surface structures [60-62]. Thus, electrochemical mediators are introduced to assist electron transfer from the microbial cells to the electrode. Mediators penetrate the bacterium cell in their oxidized form and interact with reducing agents within the cell. After being reduced, the mediators are also cell permeable and are capable of diffusing out of the cells to attach to the electrode surface. Then, the reduced mediators are electrocatalytically oxidized by transfer electrons. The oxidized mediators are free to start over this cycle again [63-65]. However, the mediators are usually toxic phenolic compounds. Therefore, the longterm operation of mediated MFCs cannot be achieved and mediated MFCs have limited commercial applications [66]. Besides of the bacterial species assisted by mediators to transfer electrons above, some bacteria are able to transfer the electrons oxidized from organic matters to electrodes without the mediator. MFCs involved in bacteria, which do not need any mediator to transfer electrons, are classified as mediator-less MFC. In most of the mediator-less MFCs, the anodes are often inoculated with dissimilar metal reducing microorganisms, including the species of Shewanella, Rhodoferax and Geobacter. The performance of MFCs is impacted not only by types of microorganisms presented, but also by mechanisms of electrons transfer to anode. Several mechanisms are involved in mediator-less MFCs: bacteria can transfer electrons through self-produced mediators; electrons transfer is related to nanowires produced by bacteria; in an absence of nanowires, electrons can be transferred via the surface of bacterial cells as well [67-69]. For the self-produced mediators to transfer electrons, Rabaey et al. [18] demonstrated that Pseudomonas aeruginosa could produce electron shuttles to enhance electron-transfer rate. Geobactor and Shewanella species are capable of producing nanowires, which contribute to transfer electrons [70,71]. Geobacter sulfurreducens is a strict anaerobic chemoorganotroph which oxidizes acetate with $\mathrm{Fe}(\mathrm{III})$, $\mathrm{S}$, Co(III), fumarate, or malate as the electron acceptor and contains c-type cytochromes [72]. Bond and Lovely [5] stated that Geobacter sulfurreducens could oxidize organic substrates completely to transfer electrons to electrodes without mediators. After this statement, Gorby [20] and Beveridge et al. [52] concluded that nanowires were produced by Geobacter sulfurreducens in response to electron acceptor limitation, which resulted in the high efficiency of electrons transfer. Shewanella species is a gram-negative, dissimilatory metal-reducing bacterium found in soils, sediments, surface waters, and ground waters. They are widely studied in MFCs research area due to their ability to conserve energy for growth by using oxygen or ferric iron as a terminal electron acceptor. The electron transferring mechanisms of Geobactor and Shewanella species are well studied because they exhibit promising capabilities of electricity producing and hydrogen generating in MFCs and MECs systems, respectively. Shewanella oneidensis MR-1 could produce electrically conductive nanowires by responding to electron acceptors' limitation [73]. For electricity generation, Geobacter 
sulfurreducens could produce electricity of $2.15 \mathrm{~kW} / \mathrm{m}^{3}$ with acetate; the highest MFCs power density reported to date [74]. Besides, the production of hydrogen by Geobacter sulfurreducens was approximately $40 \mathrm{~Pa}$ (hydrogen partial pressure) after electron acceptor-limited growth with $20 \mathrm{mM}$ acetate and $20 \mathrm{mM}$ fumarate [75]. Other than using pure culture in anode of MFCs, mixed cultured microorganisms have good performances, as well. Rabaey et al. [18] reported that mixed cultures showed higher performance than isolated pure cultures in MFCs with benefit of much wider substrate utilization. There are both electrophiles/anodophiles in mixed cultures, so mixed microorganisms use natural mediators together in the same chamber. Moreover, the mixed populations would be more robust for environmental changes, for example, temperature changes, substrates loading rate changes. The mixed populations could shift metabolic pathways to make adaptation to the new environment.

\section{Substrates Oxidized by Microbes}

Many studies emphasize on exploring performance of MFCs with different substrate. The substrate is a significant factor in any biological process because it serves as carbon (nutrient) and energy source. In MFCs, the bacterial abilities to oxidize substrates and transfer electrons are directly related to production of current [76-78] stated the substrates influence not only the integral composition of the bacterial community in the anode biofilm, but also the MFCs performance, such as power density and Coulombic efficiency (CE). Besides, Liu et al. [39] regarded substrate as one of the most important biological factors affecting electricity generation in MFCs.

Many categories substrates can be fed into MFCs, such as nonfermentable substrates (acetate, butyrate), fermentable substrates (glucose, xylose, sucrose), complex substrates (domestic wastewaters, food process wastewaters, paper recycled wastewaters) [79-81]. For example, Chae et al. [9] study compared the performance of four different substrates in terms of $\mathrm{CE}$ and power density in two-chambered MFCs, which were inoculated anaerobic digester sludge. In this study, the tested substrates were acetate, butyrate, propionate and glucose, and acetate fed-MFC showed the highest CE (72.3\%), following by butyrate (43.0\%), propionate $(36.0 \%)$ and glucose $(15.0 \%)$.

Although many sorts of substrates could be oxidized by different species of bacteria, Pant et al. [63] declared that it was difficult to make comparisons of MFCs performance with different substrates. It is mainly due to researchers using different operating conditions (e.g. surface area and types of electrodes), different inoculated microorganisms, different designs and volume of reactors. Tables 1 and 2 shows some comparisons of power outputs with different substrates under different operational conditions [82].

Note: The power density normalized by surface area is calculated by the formula of

$$
P=E^{2} M F C / A \times R
$$

Where $E_{M F C}$ is measured voltage across the load, $A$ is surface area of both sides of anodic electrode, $R$ is the load.

\section{Acetate}

Acetate is the end product of several metabolic pathways for higher order carbon sources and has been chosen as substrate for MFCs in plenty of researches, especially for evaluating the performance of new MFCs components, reactor designs or operational conditions. Bond et al. [81] claimed that acetate could be a carbon source to induce electroactive bacteria, which led acetate to be used in MFCs studies extensively. And Aelterman claimed the common use of acetate was because of its inertness towards alternative microbial conversions at room temperature, such as fermentations or methanogenesis. Acetate is the most preferred substrate for electricity generation with higher power density and CE [83-85].

\section{Glucose}

Glucose is another commonly used substrate in MFCs. By some comparisons of glucose with other substrates in the same operation conditions, MFCs with glucose exhibit higher power output than anaerobic sludge [86], lower energy conversion efficiency than acetate [65] and lower Columbic efficiency declared that the lower Columbic efficiency was because of glucose might be consumed by bacteria, which could not produce electricity. This emphasizes the advantage of acetate used as substrate in MFCs.

\section{Lignocellulosic Biomass}

Lignocellulosic materials from agricultural residues are abundant, renewable and cost-effective feedstock for energy production. However,

\begin{tabular}{|c|c|c|}
\hline \multirow{4}{*}{ Advantages } & Two-chamber MFCs & Single-chamber MFCs \\
\hline & Well-controlled conditions & Increase mass transfer to cathode \\
\hline & \multirow{2}{*}{$\begin{array}{l}\text { Essentially architecture for testing concepts, e.g., bacterial activities, } \\
\text { optimizing materials }\end{array}$} & Decrease operating cost \\
\hline & & Decrease overall reactor volume \\
\hline \multirow[b]{2}{*}{ Disadvantages } & High internal resistance & \multirow[b]{2}{*}{ Loss of anaerobic condition in anode chamber } \\
\hline & $\begin{array}{l}\text { High cost due to PEM/AEM and } \\
\text { cathodic catalyst/electrolyte }\end{array}$ & \\
\hline
\end{tabular}

Table 1: Comparisons of two-chambered and single-chambered MFCs [34].

\begin{tabular}{|c|c|c|c|}
\hline Substrate & Concentration & Power output & MFC design \\
\hline Acetate & $800 \mathrm{mg} / \mathrm{L}$ & $506 \mathrm{~mW} / \mathrm{m}^{2}$ & Single-chamber \\
\hline Glucose & $500-3000 \mathrm{~g} / \mathrm{L}$ & $3600 \mathrm{~mW} / \mathrm{m}^{2}$ & Two-chamber \\
\hline Butyrate & $1000 \mathrm{mg} / \mathrm{L}$ & $305 \mathrm{~mW} / \mathrm{m}^{2}$ & Single-chamber \\
\hline Domestic wastewater & $210-220 \mathrm{mg} / \mathrm{L} \mathrm{COD}$ & $26 \mathrm{~mW} / \mathrm{m}^{2}$ & Single-chamber \\
\hline Swine wastewater & $8320 \pm 190 \mathrm{mg} / \mathrm{L} \mathrm{COD}$ & $261 \mathrm{~mW} / \mathrm{m}^{2}$ & Single-chamber \\
\hline Artificial wastewater & $300-3400 \mathrm{mg} / \mathrm{L} \mathrm{COD}$ & $170 \mathrm{~mW} / \mathrm{m}^{2}$ & Up-flow MFC \\
\hline Carboxymethyl cellulose & $1000 \mathrm{mg} / \mathrm{L}$ & $143 \mathrm{~mW} / \mathrm{m}^{2}$ & Two-chamber \\
\hline Corn stover & $\mathrm{N} / \mathrm{A}$ & $331 \mathrm{~mW} / \mathrm{m}^{2}$ & Single-chamber \\
\hline
\end{tabular}

Table 2: Power output with different substrates under different operational conditions [82]. 
they cannot be directly oxidized by microorganisms in MFCs, so some pretreatment is needed to convert lignocellulosic materials into monosaccharides [45]. Electricity generation from cellulose in a two-chamber MFC using a co-culture of bacteria was performed. The maximum power density was $143 \mathrm{~mW} / \mathrm{m}^{2}$ with ferricyanide as the catholyte. Wang et al. [72] examined the performance of a singlechamber MFC with mixed culture from corn stover, and obtained a maximum power density of $331 \mathrm{~mW} / \mathrm{m}^{2}$.

\section{Other Designs of MFCs}

Liu et al. [80] demonstrated MFCs could produce electricity from domestic wastewater with removal of chemical oxygen demand. Many types of wastewater can be used as substrates in MFCs, because the production of intermediates in wastewater helps electricity generation. Min et al. [25] demonstrated that power densities generated from swine wastewater were $45 \mathrm{~mW} / \mathrm{m}^{2}$ with two-chamber MFC and $261 \mathrm{~mW} / \mathrm{m}^{2}$ with single-chamber MFC, respectively. He et al. [26] reported that upflow MFC generated electricity with a maximum power density of 170 $\mathrm{mW} / \mathrm{m}^{2}$ from artificial wastewater.

\section{Applications of Microbial Fuel Cells}

Along with the understanding of the MFC concept, many MFCbased applications have emerged, such as wastewater treatment, microbial electrolysis cells, sediment MFCs and bioremediation. Several of MFCs applications will be explained in this section. Among those MFC-based technologies, the most immediate and useful one is as a method of wastewater treatment [66]. The electricity produced by MFCs can be used for powering other technologies, such as biologically inspired robots, some small devices, or remote devices. In addition, the voltage generated by MFCs can be used on microbial electrolysis cells (MECs), which is a modified MFC-based system to produce $\mathrm{H}_{2}$ / $\mathrm{H}_{2} \mathrm{O}_{2}$ instead of electricity. However, most of the MFCs applications are limited to lab-scale systems because of some practical difficulties, such as economic or environmental feasibilities [67].

In the aspect of environmental feasibility, using buffer solution to keep the $\mathrm{pH}$ balanced in MFC plants is not practical for largescale. Harnisch and Schröder [24] stated that adding buffer salts (e.g. phosphate or carbonate) would result in an increase of $\mathrm{CO}_{2}$ emission, even the idea of using such chemicals in practice would be noneconomic. Instead of buffer salts, using $\mathrm{CO}_{2}$ or bicarbonate to buffer the $\mathrm{pH}$ shift is a better option [77]. In the aspect of economic feasibility, the high cost of current MFC-base technologies is contributed to the electrode material cost and membrane cost. The high cost of electrode material is mainly due to the use of platinum, which is used as a catalyst. In recent years, some researchers focus on alternative catalyst to replace platinum. Some cost-effective catalysts have been examined for MFCs, such as CoTMPP, iron phthalocyanine, manganese dioxide, activated carbon or nickel powder [37]. Therefore, some modifications of the basic MFC systems or alternative component materials can help to overcome the difficulties of scaling-up MFC-based applications or technologies.

\section{Bio-Hydrogen Production}

Due to the energy intensive and environmental friendly issues, biological hydrogen (bio-hydrogen) production processes are found to be advantageous over thermochemical and electrochemical processes. Dark fermentation can produce bio-hydrogen, but the efficiency is low. For example, fermentation of carbohydrate-rich wastewater was generally less than $15 \%$ [43]. Besides, methanogenic consumption of hydrogen in the fermentation process resulted in the majority of substrates being converted to acetate or butyrate as byproducts [49].
However, conversion of these byproducts involves endothermic reactions so that these byproducts cannot be further converted to hydrogen without an external energy input [43]. Alternatively, MFCs can be modified to produce hydrogen instead of electricity by adding a small amount of electricity $(0.11 \mathrm{~V}$ theoretically) and removal of oxygen at cathode (Figure 3). By combining bacterial metabolism with electrochemistry, bio-hydrogen can be produced by the modified MFC systems, which is called microbial electrolysis cells (MECs) [29]. MECs' efficiency is relative to the power input $(>0.2 \mathrm{~V}$ typically), but it is much less than the electrical energy needed for water electrolysis at neutral $\mathrm{pH}$ (1.21 V theoretically, >1.6-1.8 V practically) [67]. For bio-hydrogen production, MEC systems are not only advantageous over electrolysis of water, but also over conventional fermentation: MECs can produce 8-9 $\mathrm{mol} \mathrm{H} / \mathrm{mol}$ of glucose while fermentation processes produce $4 \mathrm{~mol}$ $\mathrm{H}_{2} /$ mol of glucose with acetate produced $\left(\mathrm{C}_{6} \mathrm{H}_{12} \mathrm{O}_{6}+2 \mathrm{H}_{2} \mathrm{O} \rightarrow 4 \mathrm{H}_{2}+\right.$ $\left.2 \mathrm{CO}_{2}+2 \mathrm{C}_{2} \mathrm{H}_{4} \mathrm{O}_{2}\right)$. While oxygen diffusion into anode chamber in an MFC reduces electron recovery (Coulombic efficiency), MECs should have greater electron recoveries with oxygen removal from the cathode chamber.

The very first MEC system was designed by Liu et al. [40] which was only for "proof of concept" and was not optimized. This reactor was a simple two-chambered reactor consisting of two glass bottles separated by a CEM, and the gas was release from the headspace in cathode chamber and then collected. Later, some architecture of MECs were optimized by several ways, for example, increasing the size of the membrane relative to the electrode-projected surface area, using anodic electrode with larger surface area (e.g. graphite granules), reducing electrode spacing [23-26]. Cheng and Logan developed a compact MEC system, which used chemically modified three-dimensional graphite granule as electrode and an anion exchange membrane. The $\mathrm{H}_{2}$ yield of this study was ranged from 3.03 to $3.95 \mathrm{~mol} / \mathrm{mol}$ of acetic acid when the applied voltage was from 0.3 to $0.8 \mathrm{~V}$. As mentioned above, the external power source is needed to provide the energy input, which is required to drive the hydrogen production reactions in the microbial electrolysis process. In laboratory tests, two different devices are used to provide the voltage: a power supply unit or a potentiostat. Although the voltage supply in MECs is lower than that for water electrolysis, it still consumes huge amount of energy if scaling-up the reactors [44]. Thus, reducing voltage supply or providing the voltage by sustainable electricity generation processes is one of the key issues in developing the efficient and cost-effective MECs. Since the open circuit voltage of

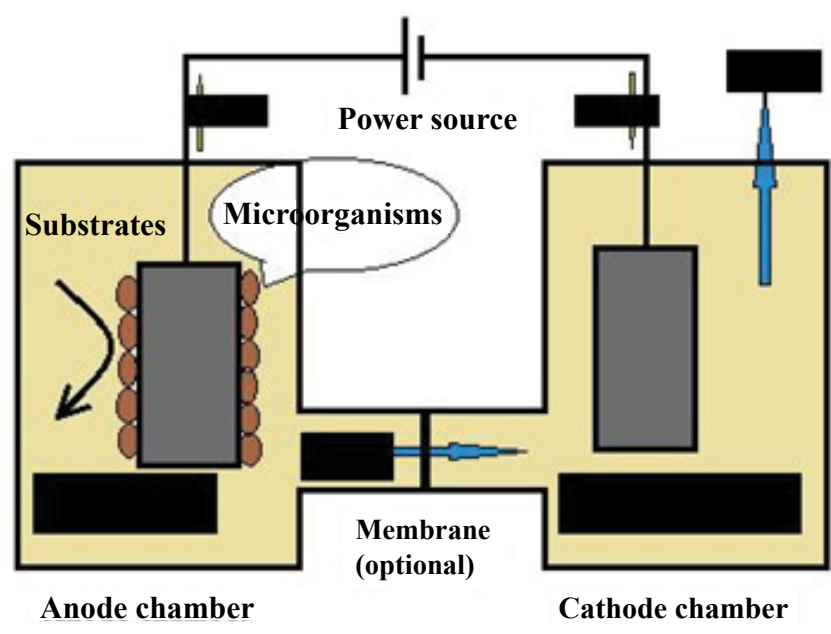

Figure 3: Operational principles of microbial electrolysis cells [3]. 
an MFC can reach as high as $0.80 \mathrm{~V}$, the voltage needed for an MEC can be supplied by an MFC. Enlightened by this idea, Sun et al. developed an MEC-MFC-coupled system for bio-hydrogen production, which means the external electric power supply for an MEC is provided by an MFC. This system is an effective way to use the power generated from MFCs. The yield of $\mathrm{H}_{2}$ in the MEC was $1.60 \pm 0.08 \mathrm{~mol} / \mathrm{mol}$ of acetate with $100 \mathrm{mM}$ of phosphate buffer in the MFC. Moreover, Sun et al. [80] examined that hydrogen production could be significantly enhanced if several MFCs connected in series to supply power for the MEC.

Note: Often used approaches to collect produced gas: glass syringes and gas bags. As hydrogen is a small molecule that easily permeates through tubing and connections, it is very important that the reactor design is gastight with proper seals. The use of large lengths of tubing and fittings for continuous flow devices should be avoided to reduce hydrogen gas losses, especially when gas production rates are low [71]. Hydrogen can be successfully produced from cellulose, glucose, acetate, butyrate, and wastewater in MECs (Table 3). The hydrogen production rate from cellulose in an MEC was low compared to single volatile fatty acid [61]. In order to optimize the conversion of lignocellulosic biomass into hydrogen, Lalaurette et al. [36] developed a two-stage process combining dark-fermentation and electrohydrogenesis for hydrogen production from recalcitrant lignocellulosic materials, and the overall hydrogen yield was $9.95 \mathrm{~mol}$ of $\mathrm{H}_{2} / \mathrm{mol}$ of glucose. This result indicated that a higher gas production rate could be achieved using a two-stage fermentation and MEC process.

\section{Wastewater Treatment}

So far, the most successful and widely used biological technology for wastewater treatment is the activated sludge process. In the process, pumping and aeration are the predominant energy consuming, for example, $21 \%$ of the total treatment energy demand consumes by pumping and $30-55 \%$ consumes by aeration [31]. Due to the high cost of operation and huge demand of energy, alternative approaches to treat wastewater are favored. The working principle, as mentioned in the introduction section above, exhibits the ability of MFCs to treat wastewater with benefits of low energy requirement and additional energy production. The first demonstration of MFCs using domestic wastewater as the substrate was reported by Liu et al. [40]. They used single-chamber MFCs, which did not need any oxygen aeration into the cathode chamber, and the COD removing rate of domestic wastewater was up to $80 \%$. Then Rabaey et al. [66] demonstrated up to $96 \%$ of the organic matter in wastewater was converted to electricity by a tubular, single-chamber MFC, demonstrated soluble COD removal efficiency was over $90 \%$ in an up-flow MFC using artificial wastewater as substrate.

\section{Biosensor}

Besides the applications of MFCs mentioned above, another potential application of the MFC technology is to use it as a sensor for pollutant analysis [41]. Kim et al. [82] found that there was a proportional correlation between the Coulombic yield of MFCs and the strength of the wastewater. Therefore, MFCs without mediators using electrochemically-active, metal-reducing bacteria are a good approach to examine biological oxygen demand (BOD) in wastewater. Furthermore, Moon et al. [10] did some efforts to optimize the response time and sensitivity of MFCs used as continuous BOD sensor. There are some advantages of using MFCs as BOD sensor, such as microorganism variety, operational stability and high accuracy [52].

\section{Sediment MFCs}

Another exciting application in microbial fuel cell research is the development of an MFC that can harvest electricity from the organic matter in aquatic sediments [42]. The purpose of sediment MFC design is to power devices placed on the seafloor or under water environment, where it will be expensive and technically difficult to exchange traditional batteries routinely, and the sediment MFC is also known as benthic unattended generators (BUGs) [33]. The idea of sediment MFC design is to place the anode into the anaerobic sediment and place the cathode into the overlying water containing dissolved oxygen. As the exoelectrogenic bacteria are rich in the sediments, the sediment MFCs are ready to produce electricity. Reimers et al. [72] proposed that the sediment-anode combined with seawater-cathode configuration harvested energy from the net oxidation of marine sediment organic matter.

\section{Life Cycle Assessment of MFCs}

As microbial fuel cells and microbial electrolysis cells are recently developed technologies, the environmental costs and benefits of MFCs and MECs have to be verified. This can be done by life cycle assessment (LCA), which is a technique to access the potential environmental impacts caused by a process or a product. The results of LCA reveal the true potential and identify the environmental impacts associated with the evaluated product or process, for example, energy and materials usage, waste discharges, impacts of these wastes on the environment [26]. Foley et al. [18] conducted a LCA to compare the environmental impacts of three technologies of wastewater treatments: anaerobic treatment (biogas generation), a microbial fuel cell (direct electricity generation) and a microbial electrolysis cell (hydrogen peroxide production). In this study, the major conclusion was that a microbial electrolysis cell provided more significant environmental benefits compared to anaerobic wastewater treatment, however, a microbial fuel cell did not. More specifically, the MEC had more significant net positive impacts than both anaerobic digestion and the MFC, and anaerobic digestion treatment had more significant net positive impacts than the MFC. Although the positive benefits in the MFC (electricity generation) were large enough, there were two underlying drawbacks: the attendant uncertainty in the data and the calculation, and the contingent result on optimistic design assumptions. In addition, they

\begin{tabular}{|c|c|c|c|c|c|}
\hline Substrate MEC design & Cathode catalyst & $\mathrm{H}_{2}$ production rate $\left(\mathrm{m}^{3} \mathrm{~m}^{-3} \mathrm{day}^{-1}\right)$ & Power supply (V) & Reference & Substrate MEC design \\
\hline Acetate & Two-chamber & $0.5 \mathrm{mg} \mathrm{Pt} / \mathrm{cm}^{2}$ & 0.37 & 0.45 & [18] \\
\hline Acetate & Two-chamber & $0.5 \mathrm{mg} \mathrm{Pt} / \mathrm{cm}^{2}$ & 0.37 & 0.45 & [18] \\
\hline Glucose & Two-chamber & $0.5 \mathrm{mg} \mathrm{Pt} / \mathrm{cm}^{2}$ & 1.23 & 0.6 & [11] \\
\hline Butyrate & Two-chamber & $0.5 \mathrm{mg} \mathrm{Pt} / \mathrm{cm}^{2}$ & 0.45 & 0.6 & [11] \\
\hline Wastewater & Two-chamber & $0.5 \mathrm{mg} \mathrm{Pt} / \mathrm{cm}^{2}$ & 0.01 & 0.5 & [15] \\
\hline Cellulose & Two-chamber & $0.5 \mathrm{mg} \mathrm{Pt} / \mathrm{cm}^{2}$ & 0.11 & 0.6 & [15] \\
\hline Swine Waste & Single-chamber & $0.5 \mathrm{mg} \mathrm{Pt} / \mathrm{cm}^{2}$ & 1 & 0.5 & [18] \\
\hline Glycerol & Single-chamber & 10 wt. \% Pt & 2 & 0.9 & [77] \\
\hline
\end{tabular}

Table 3: Comparisons of the $\mathrm{H}_{2}$ production performance of MECs with different substrates and power supplies [53]. 
concluded that the MEC had highly positive benefits due to it could directly produce pure $\mathrm{H}_{2} / \mathrm{H}_{2} \mathrm{O}_{2}$ without greenhouse gases emission.

\section{Conclusion}

Microbial fuel cells (MFCs) are new types of bioreactors that use exoelectrogenic biofilms for electrochemical energy production. In recent years, a large number of studies have been conducted to explore microbial fuel cells in many aspects, such as electron transfer mechanisms, enhancing power outputs, reactor developments and applications. Although MFCs are a promising technology for renewable energy production, they face several challenges, as well. For instance, they possess low levels of power density, scale-up feasibility, high cost of component materials, and large internal resistance. In the author's opinion, combinations of MFCs or MECs with other high value byproducts generating processes have a bright future in sustainable energy research.

\section{Recommendation}

For full understanding of microbial fuel cell (MFC), knowledge of multiple technological disciplines is required, such as electrochemistry, microbiology, material science and engineering, molecular biology and environmental engineering. It is a challenge for any research team or student to completely understand all of the theories and techniques used in the study of microbial fuel cells. Electrochemical/analytical techniques have an essential role to play in this continuous process; they are vitally important in the analyzing the limiting performances of each component, to optimize MFC operation, and to allow continued innovation. The continuous and long term operation of MFCs mandates that systems must be run under conditions that are generally predefined by the requirements for optimal microbial growth and sustainability. Typical conditions such as ambient temperatures and pressures, electrolyte and $\mathrm{pH}$. There are many factors that affect MFC performance and even one small, seemingly insignificant substantial deterioration in performance. The correct choice of experimental technique for any research objective is very important. The fact that microbial fuel cell is capable of generating electricity no matter how small, shows that microbial fuel cell could help in reducing the damage to our environment and household appliances. Therefore, I recommend this technology to all power generating plants and government parastatals. I recommend this technology to all industries and domestic wastewater treatment plants who undertake treatment of any kind of wastewater. Research is a vital tool for any meaningful development. To this end I recommend the governments and companies to intensify research into this field, in terms of financing, equipments of laboratories and encouragement of young minds, to produce a viable clean and sustainable energy source to save our planet. I strongly recommend that microbial fuel cell power generation using brewery wastewater and cheaper catholyte (Distilled water and salt) be encouraged under the guidance of experts in the field.

\section{References}

1. Aelterman P, Rabaey K, Pham HT, Boon N, Verstraete W (2006) Continuous electricity generation at high voltages and currents using stacked microbial fuel cells. Environ Sci Technol 40: 3388-3394.

2. Aelterman $P(2009)$ "Microbial fuel cells for the treatment of waste streams with energy recovery" Ph.D. Thesis, Gent University, Belgium.

3. Angenent LT, Karim K, Al-Dahhan MH, Wrenn BA, Domíguez-Espinosa $R$ (2004) Production of bioenergy and biochemicals from industrial and agricultural wastewater. Trends Biotechnol 22: 477-485.

4. Bond DR, Holmes DE, Tender LM, Lovley DR (2002) Electrode-reducing microorganisms that harvest energy from marine sediments. Science 295: 483485.
5. Bond DR, Lovley DR (2003) Electricity production by Geobacter sulfurreducens attached to electrodes. Appl Environ Microbiol 69: 1548-1555.

6. Caccavo F, Lonergan DJ, Lovley DR, Davis M (1994) Geobacter sulfurreducens sp. nov., a hydrogen- and acetate-oxidizing dissimilatory metal-reducing microorganism. Appl Environ Microbiol 60: 3752-3759.

7. Call D, Logan BE (2008) Hydrogen production in a single chamber microbial electrolysis cell lacking a membrane. Environ Sci Technol 42: 3401-3406.

8. Catal T, Li K, Bermek H, Liu H (2008) Electricity production from twelve monosaccharide using microbial fuel cells. J Power Sources 175: 196-200.

9. Chae KJ, Choi MJ, Lee JW, Kim KY, Kim IS (2009) Effect of different substrates on the performance, bacterial diversity, and bacterial viability in microbial fuel cells. Bioresour Technol 100: 3518-3525.

10. Chang IS, Moon H, Bretschger O, Jang JK, Park HI, et al. (2007) Electrochemically active bacteria (EAB) and mediator-less microbial fuel cells. J Microbiol Biotechnol 16: 163-177.

11. Cheng S, Logan BE (2007) Sustainable and efficient biohydrogen production via electrohydrogenesis. Proceedings of the National Academy of Sciences of the United States of America. 10: 18871-18873.

12. Cord-Ruwisch R, Lovley DR, Lovley B (1988) Growth of Geobacter sulfurreducens with acetate in syntrophic cooperation with hydrogen-oxidizing anaerobic partners. Appl Environ Microbiol 6: 2232-2236.

13. Dewan A, Donovan C, Heo D, Beyenal H (2010) Evaluating the performance of microbial fuel cells powering electronic devices. J Power Sources 195: 90-96.

14. Diamond D, Coyle S, Scarmagnani S, Hayes J (2008) Wireless sensor networks and chemo-/biosensing. Chem Rev 108: 652-679.

15. Ditzig J, Liu H, Logan BE (2007) Production of hydrogen from domestic wastewater using a bioelectrochemically assisted microbial reactor (BEAMR). Int J Hydrogen Energy 7: 2296-2304.

16. Du Z, Li H, Gu T (2007) A state of the art review on microbial fuel cells: A promising technology for wastewater treatment and bioenergy. Biotechnol Adv 25: 464-482.

17. Emde R, Swain A, Schink B (1989) Anaerobic oxidation of glycerol by Escherichia coli in an amperometric poised-potential culture system. Appl Microbiol Biotechnol 8: 170-175.

18. Foley M, Rozendal RA, Hertle CK, Lant PA, Rabaey K (2010) Life cycle assessment of high-rate anaerobic treatment, microbial fuel cells, and microbial electrolysis cells. Environ Sci Technol 4: 3629-3637.

19. Gil GC, Chang IS, Kim BH, Kim M, Jang JK, et al. (2003) Operational parameters affecting the performance of a mediator-less microbial fuel cell. Biosens Bioelectron 18: 327-334.

20. Gorby YA (2005) Composition, reactivity, and regulation of extracellular metalreducing structures (nanowires) produced by dissimilatory metal reducing bacteria. Presented at DOE/NABIR meeting, Warrenton, VA.

21. Gorby YA, Yanina S, McLean JS (2006) Electrically conductive bacterial nanowires produced by Shewanella oneidensis strain MR-1 and other microorganisms. Proc Natl Acad Sci 10: 11358-11363.

22. Gottesfeld S, Zawodzinski TA (1997) Polymer electrolyte fuel cell. Adv Electrochem Sci 5: 195-301.

23. Han Y, Yu C, Liu H (2010) A microbial fuel cell as power supply for implantable medical devices. Biosens Bioelectron 25: 2156-2160.

24. Harnisch F, Schröder U (2009) Selectivity versus mobility: Separation of anode and cathode in microbial bioelectrochemical systems. ChemSusChem 2: 921-926.

25. He Z, Minteer SD, Angenent LT (2005) Electricity generation from artificial wastewater using an upflow microbial fuel cell. Environ Sci Technol 39: 5262 5267.

26. He Z, Wagner N, Minteer SD, Angenent LT (2006) An upflow microbial fuel cell with an interior cathode: Assessment of the internal resistance by impedance spectroscopy. Environ Sci Technol 40: 5212-5217.

27. Hu Z (2008) Electricity generation by a baffle-chamber membrane less microbial fuel cell. J Power Sources 179: 27-33.

28. Huang L, Angelidaki I (2008) Effect of humic acids on electricity generation integrated with xylose degradation in microbial fuel cells. Biotechnol Bioeng 100: 413-422. 
29. leropoulos IA, Greenman J, Melhuish C, Hart J (2005) Comparative study of three types of microbial fuel cell. Enzyme Microb Tech 37: 238-245.

30. Jang, JK (2004) Construction and operation of a novel mediator-and membraneless microbial fuel cell. Process Biochem 39: 1007-1012.

31. Jung S, Regan JM (2007) Comparison of anode bacterial communities and performance in microbial fuel cells with different electron donors. Appl Microbiol Biotechnol 77: 393-402.

32. Kim HJ (1999) A microbial fuel cell type lactate biosensor using a metalreducing bacterium, Shewanella putrefaciens. Microbiol Biotechnol 9: 365-367.

33. Kim BH, Chang IS, Gil GC, Park HS, Kim HJ (2003) Novel BOD (biological oxygen demand) sensor using mediator-less microbial fuel cell. Biotechnol Lett 25: 541-545

34. Kim JR, Cheng S, Logan BE (2007) Power generation using different cation, anion and ultrafiltration membranes in microbial fuel cells. Environ Sci Technol 4: 1004-1009.

35. Lam MK, Lee K (2009) Life cycle assessment for the production of biodiesel: a case study in Malaysia for palm oil versus jatropha oil. Biofuels Bioprod Biorefin 11: $601-612$.

36. Lalaurette E, Thammannagowda S, Mohagheghi A, Maness P, Logan BE (2009) Hydrogen production from cellulose in a two-stage process combining fermentation and electrohydrogenesis. Int J Hydrogen Energy 3: 6201-6210.

37. Lee HS, Parameswaran P, Kato-Marcus A, Torres Cl, Rittman BE (2008) Evaluation of energy-conversion efficiencies in microbial fuel cells (MFCs) utilizing fermentable and non-fermentable substrates. Water Res 10: 15011510.

38. Li F, Sharma Y, Lei Y, Li B, Zhou Q (2010) Microbial fuel cells: The effects of configurations, electrolyte solutions and electrode materials on power generation. Appl Biochem Biotechnol 160: 168-181.

39. Liu H, Logan BE (2004a) Electricity generation using an air-cathode single chamber microbial fuel cell in the presence and absence of a proton exchange membrane. Environ Sci Technol 38: 4040-4046.

40. Liu H, Ramnarayanan R, Logan BE (2004) Production of electricity during wastewater treatment using a single chamber microbial fuel cell. Environ Sci Technol 38: 2281-2285.

41. Liu H, Cheng S, Logan BE (2005) Production of electricity from acetate or butyrate using a single-chamber microbial fuel cell. Environ Sci Technol 39: 658-662.

42. Liu H, Grot S, Logan BE (2005) Electrochemically assisted microbial production of hydrogen from acetate. Environ Sci Technol 39: 4317-4320.

43. Liu H, Cheng S, Logan BE (2005) Power generation in fed-batch microbial fuel cells as a function of ionic strength, temperature and reactor configuration. Environ Sci Technol 39: 5488-5493.

44. Liu Z, Liu J, Zhang S, Su Z (2009) Study of operational performance and electrical response on mediator-less microbial fuel cells fed with carbon- and protein-rich substrates. Biochem Eng J 45: 185-191.

45. Logan BE (2004) Extracting hydrogen and electricity from renewable resources. Environ Sci Technol 38: 160A-167A.

46. Logan BE, Hamelers B, Rozendal R, Schröder U, Keller J, et al. (2006) Microbial fuel cells: Methodology and technology. Environ Sci Technol 40: 5181-5192.

47. Logan BE, Regan JM (2006) Electricity-producing bacterial communities in microbial fuel cells. Trends Microbiol 14: 512-518.

48. Logan BE, Regan JM (2006) Microbial fuel cells--challenges and applications. Environ Sci Technol 40: 5172-5180.

49. Logan BE, Call D, Cheng S, Hamelers HVM, Sleutels THA, et al. (2008) Microbial electrolysis cells for high yield hydrogen gas production from organic matter. Environ Sci Technol 10: 8630-8640.

50. Logan BE (2009) Exoelectrogenic bacteria that power microbial fuel cells. Nat Rev Microbiol 7: 375-381.

51. Lovley DR (2006) Bug juice: harvesting electricity with microorganisms. Nat Rev Microbiol 4: 497-508

52. Lower SK, Hochella MF, Beveridge TJ (2001) Bacterial recognition of mineral surfaces: Nanoscale Interactions between Shewanellaa and -FeOOH. Science 29: $1360-1363$.
53. Madigan MT, Martinko JM, Parker J (2000) Brock biology of microorganisms. Prentice Hall: Upper Saddle River, New Jersey.

54. Manish S, Banerjee R (2008) Comparison of biohydrogen production processes. Int J Hydrogen Energy 3: 276-286.

55. Min B, Cheng S, Logan BE (2005) Electricity generation using membrane and salt bridge microbial fuel cells. Water Res 39: 1675-1686.

56. Min B, Kim J, Oh S, Regan JM, Logan BE (2005) Electricity generation from swine wastewater using microbial fuel cells. Water Res 39: 4961-4968.

57. Moon H, Chang IS, Kang KH, Jang JK, Kim BH (2004) Improving the dynamic response of a mediator-less microbial fuel cell as a biochemical oxygen demand (BOD) sensor. Biotechnol Lett 26: 1717-1721.

58. Nevin KP, Richter H, Covalla SF, Johnson JP, Woodard TL (2008) Power output and Coulombic efficiencies from biofilms of Geobacter sulfurreducens comparable to mixed community microbial fuel cells. Environ Microbiol 10: 2505-2514.

59. Niessen J, Harnisch F, Rosenbaum M, Schroder U, Scholz F (2006) Heat treated soil as convenient and versatile source of bacterial communities for microbial electricity generation. Electrochem Commun 8: 869-873.

60. Oh S, Min B, Logan BE (2004) Cathode performance as a factor in electricity generation in microbial fuel cells. Environ Sci Technol 38: 4900-4904.

61. Oh ST, Kim JR, Premier GC, Lee TH, Kim C, et al. (2010) Sustainable wastewater treatment: How might microbial fuel cells contribute. Biotechnol Adv 28: 871-881.

62. Pant D, Van Bogaert G, Diels L, Vanbroekhoven K (2010) A review of the substrates used in microbial fuel cells (MFCs) for sustainable energy production. Bioresour Technol 101: 1533-1543.

63. Pant D, Singh A, Bogaert GV, Gallego YA, Diels L, et al. (2011) An introduction to the life cycle assessment (LCA) of bioelectrochemical systems (BES) for sustainable energy and product generation: Relevance and key aspects. Renewable and Sustainable Energy Reviews 15: 1305-1313.

64. Potter MC (1911) Electrical effects accompanying the decomposition of organic compounds. Biol Sci 8: 260-276.

65. Rabaey K, Lissens G, Siciliano SD, Verstraete W (2003) A microbial fue cell capable of converting glucose to electricity at high rate and efficiency. Biotechnol Lett 25: 1531-1535.

66. Rabaey K, Boon N, Siciliano SD, Verhaege M, Verstraete W (2004) Biofue cells select for microbial consortia that self-mediate electron transfer. Appl Environ Microbiol 70: 5373-5382.

67. Rabaey K, Boon N, Hofte M, Verstraete W (2005a) Microbial phenazine production enhances electron transfer in biofuel cells. Environ Sci Technol 39: 3401-3408.

68. Rabaey K, Clauwaert P, Aelterman P, Verstraete W (2005) Tubular microbia fuel cells for efficient electricity generation. Environ Sci Technol 39: 8077-8082.

69. Rabaey K, Verstraete W (2005) Microbial fuel cells: novel biotechnology for energy generation. Trends Biotechnol 23: 291-298.

70. Rabaey I, Ossieur W, Verhaege M, Verstraete W (2005) Continuous microbial fuel cells convert carbohydrates to electricity. Water Sci Technol 52: 515-523.

71. Reguera G, McCarthy KD, Mehta T, Nicoll JS, Tuominen MT, et al. (2005) Extracellular electron transfer via microbial nanowires. Nature 435: 1098-1101.

72. Reimers CE, Tender LM, Fertig S, Wang W (2001) Harvesting energy from the marine sediment--water interface. Environ Sci Technol 35: 192-195.

73. Ren Z, Ward TE, Regan JM (2007) Electricity production from cellulose in a microbial fuel cell using a defined binary culture. Environ Sci Technol 41: 47814786.

74. Rittmann BE, Krajmalnik-Brown R, Halden RU (2008) Pre-genomic, genomic and post-genomic study of microbial communities involved in bioenergy. Nat Rev Microbiol 6: 604-612.

75. Rozendal RA, Hamelers HVM, Euverink GJW, Metz SJ, Buisman CJN (2006) Principle and perspectives of hydrogen production through biocatalyzed electrolysis. Int J Hydrogen Energy 11: 1632-1640.

76. Rozendal R, Hamelers HVM, Molenkamp RJ, Buisman CJN (2007) Performance of single chamber biocatalyzed electrolysis with different types of ion exchange membranes. Water Res 11: 1984-1994. 
77. Selembo PA, Perez JM, Lloyd WA, Logan BE (2009) High hydrogen production from glycerol or glucose by electrohydrogenesis using microbial electrolysis cells. Int J Hydrogen Energy 3: 5373-5381.

78. Sell D, Krämer P, Kreysa G (1989) Use of an oxygen gas diffusion cathode and a three-dimensional packed bed anode in a bioelectrochemical fuel cell. Appl Microbiol Biotechol 5: 211-213.

79. Sun M, Sheng GP, Zhang L, Xia CR, Mu ZX, et al. (2008) An MEC-MFCcoupled system for biohydrogen production from acetate. Environ Sci Technol 42: $8095-8100$

80. Sun M, Sheng G, Mu Z, Liu X, Chen Y, et al. (2009) Manipulating the hydrogen production from acetate in a microbial electrolysis cell-microbial fuel cellcoupled system. Power Sources 19: 338-343.

81. Tender LM, Reimers CE, Stecher HA 3rd, Holmes DE, Bond DR, et al. (2002) Harnessing microbially generated power on the seafloor. Nat Biotechnol 20: 821-825.
82. Trinh NT, Park JH, Kim BW (2009) Increased generation of electricity in a microbial fuel cell using Geobacter sulfurreducens. Korean J Chem Eng 26: 748-753.

83. Wang $X$, Feng $Y$, Wang $H, Q u Y, Y u$, et al. (2009) Bioaugmentation for electricity generation from corn stover biomass using microbial fuel cells. Environ Sci Technol 43: 6088-6093.

84. Wagner RC, Regan JM, Oh SE, Zuo Y, Logan BE (2009) Hydrogen and methane production from swine wastewater using microbial electrolysis cells. Water Res 43: 1480-1488.

85. Zhao F, Harnisch F, Schröder U, Scholz F, Bogdanoff P, et al. (2006) Challenges and constraints of using oxygen cathodes in microbial fuel cells. Environ Sci Technol 40: 5193-5199.

86. Zhou M, Chi M, Luo J, He H, Jin T (2011) An overview of electrode materials in microbial fuel cells. J Power Sources 196: 4427-4435. 